\title{
Ethnographic Events in Vojvodina as Part of Tourist Offer
}

\author{
Bjeljac, Željko' \\ Curčić, Nevena
}

\begin{abstract}
The territory of Autonomous Province of Vojvodina as multiethnic area comprises about thirty different nations. In this society there is a great number of different kinds of traditions, folklore and customs. The rich multicultural and multiethnic tradition of this area enables the organization of different tourist events. Their base can be found in ethnographic wealth of the Vojvodina region. Ethnographic events are the sign of folk customs, beliefs, rituals, and ancient forms of productive work (labour). Particularly important are: celebrations of successful harvest, folklore dances, ancient magical or religious rituals and economic - folklore events and festivals. As such, ethnographic events have important place in the tourist offer of Vojvodina.
\end{abstract}

Key words: Vojvodina, ethnographic events, tourist offer, tradition, folklorea

\section{1 Željko Bjeljac}

Geographical Institute "Jovan Cvijic", Serbian Academy of Science and Arts, Djure Jaksica 9, Belgrade, Serbia, e-mail: zbjeljac@yahoo.com

\section{Nevena Ćurčić}

Department of Geography, Tourism and Hotel Industry, Faculty of Natural Sciences, University of Novi Sad, Novi Sad, Serbia, e-mail: galant@ptt.yu

\section{Introduction}

In the present tourist offer event tourism can contribute to broader tourist demand and interest. It would be more appropriate to classify them in accordance with their contents: artistic, scientific, economic, sports, religious, political or historical, ethnographic, entertainment, and tourist promotional events (Bjeljac $Z$, 2001).

According to Janiskee (1994), "this is the age of special events". Described as a one-time or infrequently occurring event of limited duration that provides consumers with leisure and social opportunity beyond everyday experience (Jago and Shaw, 1998), observation and anecdotal evidence suggest that the number of special events has increased substantially over time (Getz 1991; Getz and Wicks 1993; Janiskee 1994). Influencing both day trip and overnight visits, special event tourism is an important motivator of travel, whereas special event tourism is one of the fastest growing segments of the tourism in dustry (Backman at all 1995). This is due to the ability of events to contribute to a city's range of tourist attractions, facilitate media coverage for the destination, and promote awareness of the destination for future visits.

The above authors note that festivals and events have been elements of community tradition for a long time, are growing in number and variety, and are significantly linked with tourism. Although events attracting international visitors are of major importance, there is also recognition of the role played by local events in contributing to harmonious relationships among people of differing backgrounds within a country. It is widely submitted that community pride and internal relationships may strengthen through involvement in organization of an event, whereas visitors may acquire greater understanding and appreciation of the community traditions and way of life. Small-scale events such as village festivals draw visitors from surrounding districts and may help give visitors from urban areas a more accurate perception of rural life.

This aspect of events may best seen in local wine and food festivals with folklore customs (ethnographic), usually heavily dependent on voluntary inputs, and pro- viding means by which communities can confirm and communicate pride in their local products. It presented as a commemoration of the region's heritage, expressed in fine wine, food, music and art and is organized by a committee, with the support of over one thousand volunteers from the local community. Many events are there - such as local foods, wines, folklore and craftwork - at which a visitor can see or even participate in a genuine manifestation of the local community way of life. Although they obviously staged, historical re-enactments, if faithfully rendered, can contribute to a visitor's understanding of a community's formative influences.

The strengths of events in the current context lie in their ability to bring large numbers of people together in circumstances where they can share experiences with and learn to look at the world through the eyes of others.

These attributes can be deemed strengths only insofar as they contribute to the goal of a more harmonious world. Unfortunately, the strengths may be insufficient or may not always work in the desired direction. Even events of a more positive nature are limited in their impact for a number of reasons. Although attendance at an event may provide visitors with intercultural contacts, the experience is fleeting and still relatively superficial.

Certain events, particularly cultural festivals and ethnographic ones, are valued because they emphasize the differences, rather than the commonality, between hosts and visitors, a generally divisive process referred to as "othering". Events may also share with mainstream tourism a condition of inequality between host and visitor - a condition not conducive to the kind of relationship desired.

It appears that, while events may be a major factor in the success of a destination's tourism industry, there are many which contribute only economic advantage, and which may even create division and reinforce pre-existing prejudices. It is claimed that as travel becomes a more popular leisure activity, travellers become more confident and sophisticated (Pearce, 1988; Ross, 1994), and are likely to seek more meaningful travel experiences, involving the deeper and more extended in- 


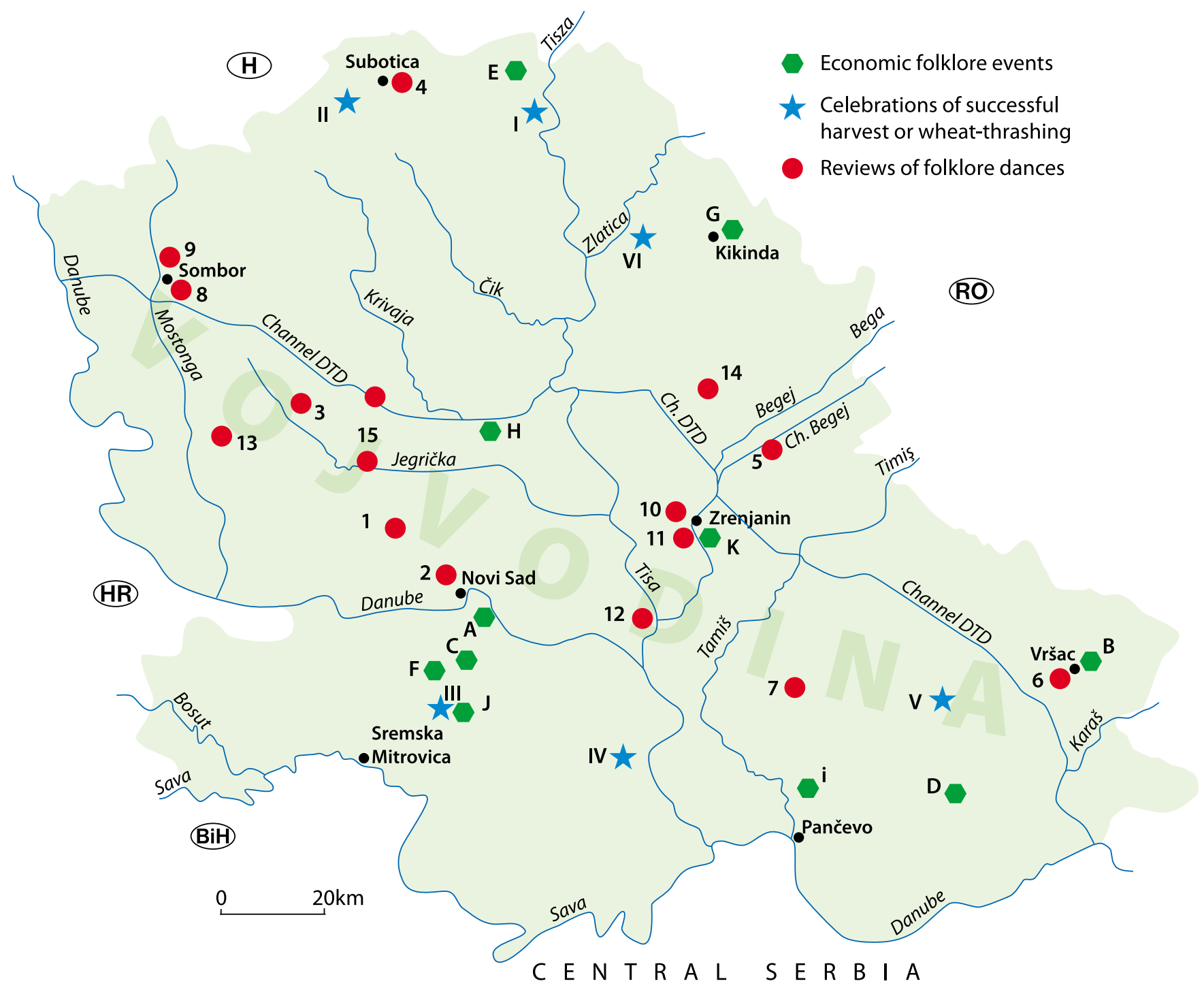

Figure 1 Geographical position of ethnographic events in the Vojvodina region. Details in tables

teraction with host communities which events offer. In conjunction with this is the widespread promotion of sustainability as an objective in all areas of human activity, and a corresponding increase in adoption of the ecotourism ethic, with its emphases on conservation, education and host community wellbeing. Another development that may offer opportunities is the expansion of tourism education in colleges and universities, providing a channel for the encouragement of enlightened attitudes and appropriate skills in travellers and event managers.

The cultural aspects of the way of life of a place and a "sense of community" help us better understand to the processes of change being experienced in Vojvodina.

It is important to define what a sense of community and place actually are. It is useful to assess all key factors that contribute to making effective events and how a community's sense of itself and its place emerge as major elements. "It is evident that a historical perspective allows a strong narrative to emerge, which in turn demonstrates the values, interests and aspira- tions of a host community. Though hard to define, it includes a community's image, spirit, character, pride, relationships and networking" (Bush, 2002). A sense of community comes from a shared vision, where a clear sense of purpose values individual ideas and contribution and involves working together on community issues, celebrations and problem solving. "Developing a sense of community is a challenging long-term work that builds levels of connection, belonging and support" (Duga \& Schweitzer, 1997). Festivals and cultural events observed provide a forum for the shared purpose to be manifest. Dunstan (1994) suggests that "festivals can be used to build communities. Organizing a major festival takes a lot of individual and collective effort. To get the job done the organizers have to be able to give a lot of time personally and be able to call in many favors and/or inspire volunteerism. Celebration can bind a community and they can be the instrument that keeps community a fresh and constantly renewing experience. Annual festivals create a community of witness that marks the passage of time. Celebration is the way humans integrate change". "Community cultural festivals help creates communities of values (Ulrich, 1998) by forging strong and distinct identities".

The ethnic heterogeneity of the population in Vojvodina caused the existence of different forms of expressing its specifics (the traditions of living, customs, religion, economic ways, time and conditions of settling and others). The rich multicultural and multiethnic tradition of this area enabled the stimulus for organizing the tourist events. Their base is ethnographic wealth of the region of Vojvodina.

Tourist destinations in Vojvodina, where event tourism is either dominant one or one of the dominant forms of tourism are of two kinds: tourist transit routes and tourist regions. The transit routes: Horgos-Subotica-Novi Sad-Belgrade (branch B of Pan European Corridor 10 Budapest-BelgradeNis- Skopje-Thessalonica) and Sid-Sremska Mitrovica-Ruma-Belgrade (as branch B of Pan European Corridor 10 Graz-MariborZagreb-Belgrade-Nis-Sofia) and the river Danube (as direction of Pan European Cor- 
ridor 7). These are the most important routes for the tourist destinations in Vojvodina. Within these destinations are urban tourist centers Novi Sad, Subotica, Vrsac and Sombor. Other important tourist destinations in Vojvodina are tourist regions: Banat sandy terrain, Lower Tisa Basin, Upper Tisa Basin, Fruska Gora Mountain and Upper Danube Basin (Bjeljac Z, Curcic N, 2003).

Event tourism is an important part of the total tourist offer of Vojvodina. Great diversity of traditions among the population and events supported by natural geographic values and with better tourist promotion and propaganda may form a basis for a better understanding among the potential tourists of what the destination has to offer; this will lead to an exchange of artistic, scientific and other achievements. Moreover, event tourism is a sort of a "bridge" for the cooperation Vojvodina with the mother - countries of the Vojvodinian ethnic minorities (Czech Republic, Slovakia, Croatia, Hungary, Romania, Bosnia and Herzegovina, Ukraine, Germany etc) in the matters of economy, culture, sports, science and technology.

\section{Ethnographic events}

Since the 1980's, "Eventing" and the terminology that has been applied to Events and Celebrations has become a "little less poetic and spiritual in nature, and a whole lot more economic and strategic" (Aitken I, 2002). „Ethnographic events are a showing of folk customs, beliefs, rituals, and ancient forms of productive work. Particularly important are: celebrations of successful harvest or wheat-thrashing, reviews of folklore dances, ancient magical or religious rituals and economic - folklore events and festivals" (Bjeljac Z,1998).

In Vojvodina, according to the Calendar of tourist events in Serbia (Tourist Organization of Serbia, 2005) and data from Secretariat for Economy of the Province of Vojvodina, there were 244 tourist events held. Concerning ethnographic ones, there were 36 events held (or $14.75 \%$ from all events in Vojvodina). Those events were visited by $200,000-300,000$ tourists from Serbia and foreign countries.

\section{Celebrations of successful harvest or wheat-thrashing}

Events happening at the time of celebrating successful harvest or wheat-trashing, which are based on the tradition of preserving national ways of economy, have their own special characteristics due to different traditions. Those special characteristics, enriched with entertainment and art programmes and associated with other socio-geographic characteristics of the place and region where they take place, present the content of the tourist offer of Vojvodina, which can contribute to the increase in

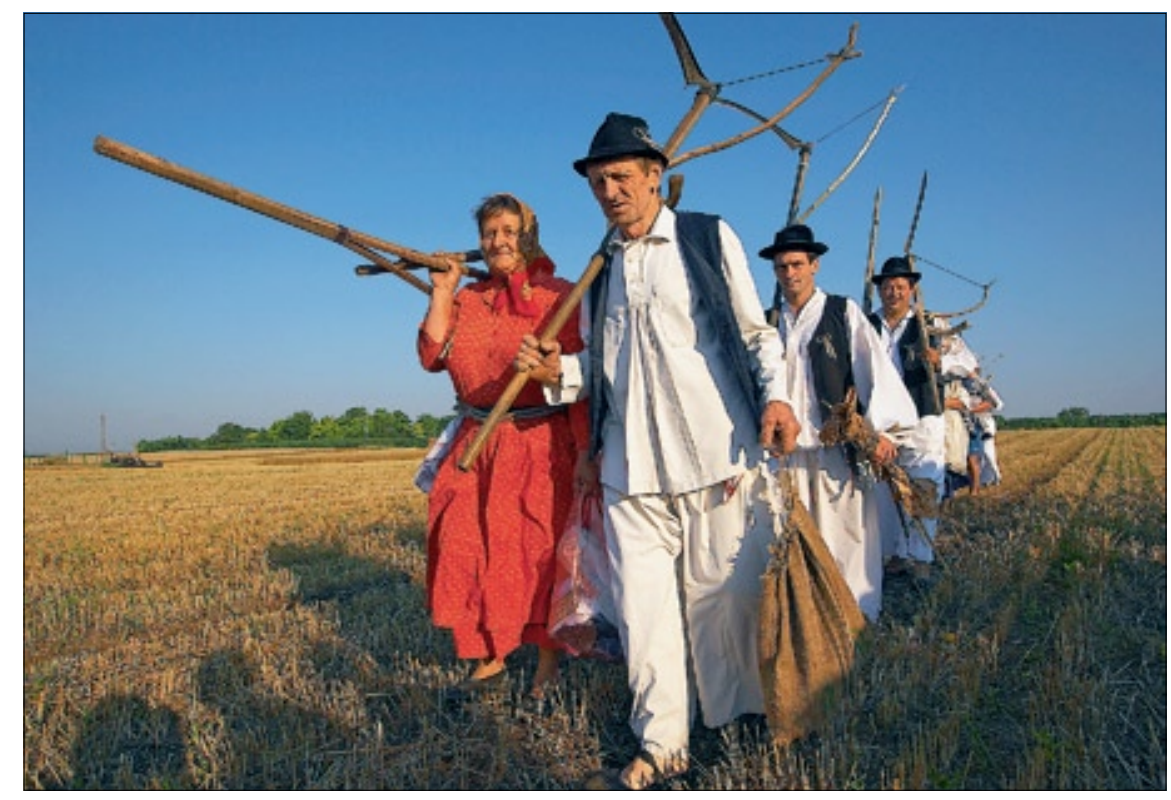

Figure 2 Harvest competition (Photo by I.Marinović) the tourist market. Festivals for successful harvest and trashing are held during July. They are of regional-republic rank; they attract the significant number of guests and have various festivities, which include entertaining, artistic, sport, religious and sometimes political content. There are six outstanding events that are held for celebrating successful harvest and trashing. They are also significant as a part of the tourist offer of Vojvodina.

Dužijanca is organized at the territory of the community of Subotica, being one of the oldest tourist events at the territory of Vojvodina dedicated to the celebration of successful harvest. It presents the customs that originate from the harvests of Bunjevci people. Until the beginning of the XX century, celebrations of successful harvest took place in the fields, and the participants were the guests at the same time. From 1911 to the beginning of the World War II, the public festival takes place in Subotica. From 1948, with the organization in Tavankut, Dužijanca gets the profane character. As an event with the tourist significance, it revives in Ljutovo in 1966 and in Subotica, Tavankut, Palić and Kelebija in 1968, since when it has been organized permanently. The competitions of the harvesters (harvester swath), tractor drivers, combine harvester drivers; expositions of the primitives; tourist dance; ex- positions of the straw works; big harvesters' party; gathering of the towns of Osijek, nival; procession of the people in national attires.

Participant harvesters come from Serbia, Croatia, Hungary; folklore ensembles come from Serbia, Croatia, Bosnia and Herzegovina, Former Yugoslav Republic of Macedonia, Slovenia, Hungary, Rumania, Czech Republic, Slovakia, Poland, Ukraine, Germany, France and Greece. The average of the active guests is 1500 2000 (mowers, harvesters, cultural and artistic social clubs, painters, etc), and the average of guests is $25000-3000$. In last two years, there has been a significant increase in the number of guests and participants, especially from Croatia and Hungary (data from the cultural and artistic social club Bunjevačko kolo).

Harvesters Days represent the folklore customs that take place during the harvest among the Serbian people in the community of Ruma. Events organized for the occasion are: Harvesters' Eve, as a variety of the cultural and artistic programme in the centre of Ruma, when the best harvesters team is being selected and where the guests also take part. The entertainment is followed by the traditional cooking that is characteristic for this part of Srem. As part of Harvesters' Days, there is also a tourSombor and Subotica; race meeting; car-

Table 1 Celebrations of successful harvest or wheat-thrashing

\begin{tabular}{|c|l|l|l|}
\hline $\begin{array}{c}\text { On } \\
\text { fig } \mathbf{1}\end{array}$ & Event & Place & Date \\
\hline I & Days of the New Bread & Kanjiža & On the first half of Jull \\
\hline II & Dužijanca & Subotica & Jull and August \\
\hline III & Harvesters' Days & Ruma & The first week on Jull \\
\hline IV & Golden Ear & Stara Pazova & On the first half of Jull \\
\hline V & Harvest Days & Alibunar & The first week on Jull \\
\hline VI & North Banatian Harvest Festival & Sajan & On the end of the Jull \\
\hline
\end{tabular}


ist presentation of Dragačevo followed by the appropriate cultural and artistic entertainment. The number of the guests is up to 3000o. (data from the Tourist Organi-

Apart from these, very interesting are also the celebrations of the successfil harvest Days of the New Bread (Kanjiža) and North Banatian Harvest Festival (Sajane, municipality of Kikinda) that are based on the tradition of folklore and economy of the Hungarian people in Vojvodina; Golden Ear (Stara Pazova) that is based on the tradition of folklore and economy of the Slovak people in Vojvodina and Harvest Days (Alibunar), that are tradition of folklore and economy of the Rumanian people in Vojvodina. Considering that these events represent tradition of folklore and economy of the national minorities, they're valuable for tourism, not only as an element of the attractive tourist offer, but also as the basis for directing tourist market towards their countries of origin. The celebrations of the successful harvest are together with the entertainment tourzation of Ruma)

ist events, the only events where the tourist organizations are the founders, independently or in partnership with others.

\section{Folklore dances events}

On the territory of Vojvodina, what are also organized are the events that represent various achievements and beliefs through the tradition and lifestyle of the ethnically heterogeneous population in Vojvodina. These are events of folklore dances and of customs. According to their special characteristics, there are 15 the most significant ones.

The events listed above usually have a provincial rank, but sometimes they are of international character. Most usually those events of folklore and customs are based on the living tradition of the national minorities of Vojvodina with the occasional visits of folklore ensembles and cultural and artistic social clubs from their countries of origin. The ethnical heterogeneity, rich anthropogenesis and cultural heritage have caused that, in Vojvodina, there are also organized reviews of folk-

Table 2 Reviews of folklore dances

\begin{tabular}{|c|c|c|c|}
\hline $\begin{array}{l}\text { On } \\
\text { fig } 1\end{array}$ & Event & Place & Date \\
\hline 1 & Slovak Folk Festivals & Bački Petrovac & beginning of August \\
\hline 2 & $\begin{array}{l}\text { Spring in the Granges of } \\
\text { Čenej }\end{array}$ & Čenej & $\begin{array}{l}\text { On the second half of } \\
\text { August }\end{array}$ \\
\hline 3 & Red Rose & Ruski Krstur & 01-03 July \\
\hline 4 & Đenđeš Bokreta and Durindo & $\begin{array}{l}\text { Annually in a different } \\
\text { place? }\end{array}$ & In the first half of June \\
\hline 5 & $\begin{array}{l}\text { Festival of Music and Folklore } \\
\text { of the Rumanian people in } \\
\text { Voyvodina }\end{array}$ & $\begin{array}{l}\text { Annually in a different } \\
\text { place }^{2}\end{array}$ & $\begin{array}{l}\text { In the second half of the } \\
\text { September }\end{array}$ \\
\hline 6 & $\begin{array}{l}\text { International Festival of } \\
\text { Folklore "Vršački venac" }\end{array}$ & Vršac & $\begin{array}{l}\text { In the second half of the } \\
\text { August }\end{array}$ \\
\hline 7 & $\begin{array}{l}\text { Festival of Music and Folklore } \\
\text { of the Slovak People in } \\
\text { Voyvodina "Tancuj Tancuj" }\end{array}$ & $\begin{array}{l}\text { Annually in a different } \\
\text { place }^{3}\end{array}$ & $\begin{array}{l}\text { On the beginning of } \\
\text { September }\end{array}$ \\
\hline 8 & $\begin{array}{l}\text { International Children } \\
\text { Festival of Folklore "The } \\
\text { Smile of the Sombor" } \\
\end{array}$ & Sombor & To the end of May \\
\hline 9 & $\begin{array}{l}\text { International Festival of } \\
\text { Folklore }\end{array}$ & Sombor & On the middle of Jull \\
\hline 10 & $\begin{array}{l}\text { International Festival of } \\
\text { Folklore CANTEMUS }\end{array}$ & Zrenjanin & To the end of June \\
\hline 11 & $\begin{array}{l}\text { International Festival of } \\
\text { Folklore "LALA" }\end{array}$ & Zrenjanin & 24-29 August \\
\hline 12 & Šajkaš Folklore Dances & $\begin{array}{l}\text { Annually in a different } \\
\text { place }^{4}\end{array}$ & On the end of August \\
\hline 13 & Redhead Goddess & Odžaci & $\begin{array}{l}\text { In the second half of } \\
\text { May }\end{array}$ \\
\hline 14 & "Winter Customs Holiday" & Torak & 24-25 December \\
\hline 15 & Review of Carts and Horses & Ravno selo & In the middle of Jull \\
\hline
\end{tabular}

where the Hungarian people are the majority

${ }^{2}$ where the Rumanian people are the majority

${ }^{3}$ where the Slovak people are the majority

${ }^{4}$ of the historic region of Šajkaš lore dances that represent the living tradition of the people of same countries in the world. The following programme is rich in artistic, sport, entertaining and sometimes religious content.

As one of the oldest events on the territory of Serbia, Slovak Folk Festivals are organized in Bački Petrovac. The first festival was organized in 1919. The organizer of the festival that lasts for three days at the beginning of August is Matica of Slovaks. The programme includes: procession of the Slovak people in their national attire accompanied with dancing and singing; meeting of the Slovak teachers; expositions of Slovak painters and Slovak writing; plays by Slovak amateur theatres; review of Slovak folklore; office in Evangelist church with a concert of ecclesiastical songs; sport competitions. The number of guests sometimes exceeds 1000o. (Data's from the Matica of Slovaks).

In the organization of the Music Ensembles Union and the Cultural and Educational Community of Vojvodina, Festival of Hungarian Folklore Dance and Playing Music on the Archaic Instruments "Đenđeš Bokreta" has been organized since 1963 , as well as Festival of Folklore of the Vojvodinian Hungarians "Durindo" since 1977. The programme of the festival includes concerts of the folklore groups, orchestras and solos; expositions of the paintings; literary meetings. The guests are four folklore ensembles of other nations and national minorities of Vojvodina, and sometimes folklore groups from Hungary. The place where the festival is organized changes; each year it is held in a different place where the Hungarian people are majority. Depending on the place, the number of visitors varies from 3500 to 5000 , and the number of participants is over 2000 in more than 100 folklore groups. (data from the newspaper Magyar Szo)

Apart from being opened toward the countries of origin, specific characteristics of the listed events are that they are opened towards the rest of the foreign market as well. Disadvantage is that there are no appropriate accommodations objects in the listed places. However, by accommodating guest in private accommodation, a kind of country tourism can be developed.

The event that represents traditional folklore dances and lifestyles on authentic is Spring in the salas frams of Čenej (PČESA). The organizers are Tourist organization of Novi Sad and PČESA society. The event includes musical and dancing performances of the Vojvodinian folklore dances; "World championship in pair dances"; literary meetings; expositions; presentation of the life on salas farms. Sometimes there are even participants from Hungary. Guests usually come from Novi Sad and surrounding places, and by means of tour- 
ist marketing there are possibilities for attracting the guests from abroad. PČESA as an institution was founded in order to preserve the lifestyle as a specific element of the life in Vojvodina.

\section{Ancient magical or religious rituals}

Magical or religious rituals (Shrovetides and processions) are magical or religious acts, which are based on traditional folklore customs and beliefs. "Shrovetide customs is the period of six weeks before Easter and precedes the Easter diet" (Marjanović, 1990). These rituals coincide with the coming of the new vegetation period. They represent the rituals that mark the beginning of spring, and also mark the preparations for the Easter diet. Three types can be identified: Shrovetides in the communities of catholic population in Vojvodina, Phasangs and Dodols (processions) in the communities of orthodox population in Vojvodina and in the communities where Hungarian and Croatian people of Vojvodina are the majority (Doroslovo, Golubinci, Novi Slankamen, Kanjiža, Subotica, Tavankut, Cantavir, Sajane, Kupusina, Senta, Horgoš, Bezdan and others) there are processions called white processions. Customs of the Shrovetides in these communities have been held for several hundred years and have the following sequence:

- masked processions are organized, followed by various apparitions, while the processions of women in folklore attires walk through the centre of a community singing folklore songs accompanied by musicians.

- as a closing ceremony in the evening of the third day, the masquerade is organized

In the community of Rumanians (village Grebenac) Shrovetides (phasang) can last up to seven days. The carts with horses and the tractors with sidecars are prepared. Each sidecar carries the masked participants who represent a certain theme from the life of the village. They are followed by groups of "bears" with a "keeper" and a "musician", as well as the small groups of masked young men. On the second day, "Shrovetides wedding" comes. After the walk, the procession stops in front of the Cultural centre and the dance begins. Most usually young men dressed in folklore attire take part in the masked procession. They are called Kalushars. They have leather belts with little bells around their legs. They walk the streets accompanied by the musicians. In the evening, people gather in the Cultural centre where the musical show with sketches takes place.

Magical or religious rituals have local I regional character, and they are usually attended by the inhabitants of the very places as well as by nearby places and cas-

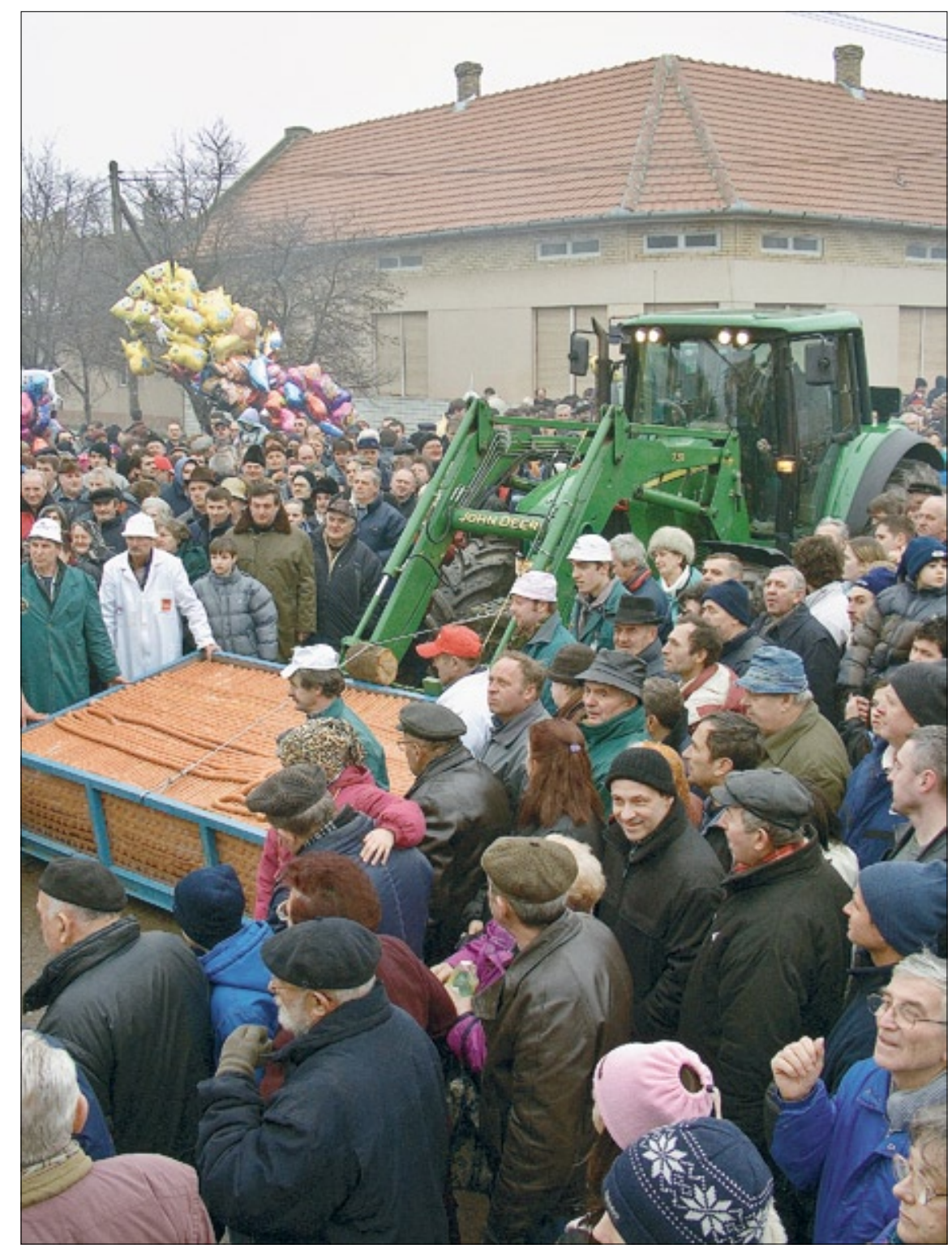

Figure 3 Sausage days in Turija (Photo by V.Lazić) ual guests. Shrovetides have tradition that lasts for centuries and thus they have significant but rather unused potential. Main reason for them being unused is unconcern of the tourist organizations and cultural and educational communities.

\section{Economic - folklore events}

Those are the events that, in an entertaining way but with a respect towards tradition of folklore and economy of the people in Vojvodina, represent their products, mainly agricultural. Thereat, economic

Table 3 Economic-folklore events

\begin{tabular}{|c|l|l|l|}
\hline $\begin{array}{c}\text { On } \\
\text { fig } \mathbf{1}\end{array}$ & Event & Place & Date \\
\hline A & Vintage Days & Sremski Karlovci & $\begin{array}{l}\text { To the end of September } \\
\text { or beginning of October }\end{array}$ \\
\hline B & Vintage Days & Vršac & 16-18 September \\
\hline C & Vineyard Guards' Days & Irig & 22-24 September \\
\hline D & Beekeepers' Meeting & Deliblat Sand & To the end of June \\
\hline E & Vintage Days & Horgoš & September \\
\hline F & Melon Days & Rivica & 06.-07 August \\
\hline G & Pumpkin Days & Kikinda & 07-o9 October \\
\hline H & Sausage Days & Turija & 25-27 February \\
\hline I & Bacon Days & Kačarevo & 17-20 February \\
\hline J & Srem Pig Butchering & Ruma & On the end of November \\
\hline K & Beer Days & Zrenjanin & 26 August - o4 September \\
\hline & & & \\
\hline
\end{tabular}


significance is primary, because the goal of the event is presenting and selling products and presenting traditional tools and engines, as well as the ways of economy. According to the type of the agricultural product, they can be dedicated to vintage, melons, meat products and other agricultural products. In Vojvodina, there are 11 significant economic - folklore events that are attractive to tourism.

Most of the listed events are mainly fairs. Native Social Club in Irig has been organizing Vineyard Guards' Days since 1993. It lasts three days in the middle of September. During the event, trade exposition of grape and wine is set, and there are organized competitions for the best vineyard, best wine, best schnapps.

There are organized vineyard guards' neighborly joined work, vineyard guards' lunch, vineyard guards' entertainment evening, enological exposition, and vineyard guards' processions. Participants are winegrowers from Serbia and Croatia, and the number of guests is up to 30000 .

\section{Conclusion}

It critically analyses the challenges facing communities using ethnographic events to deliver complex social, political and cultural outcomes. It seeks to establish how this kind of events develop and manage the tensions generated by different community voices. A signifier of a community's sense of self and an expression of its sense of place is the collaboration that occurs when events such as the Duzijanca in Subotica, Harvesters Days in Ruma, Vineyard Guards Days in Irig, Pumpkin Days in Kikinda and ethnographic events of national minorities in Vojvodina are hosted. Community cultural festivals and ethnographic events are a phenomenon in a real life context that can be examined in a descriptive manner. Evidence deals holistically with who, why, how, what, when and where of case studies exploring simi- larities and differences in the nature of the festival.

Ethnographic events in Vojvodina with their various programmes, apart from socio - economic and cultural and artistic significance, also have tourist effects on the place of their happening. Such effects can be noticed in the richness of programme, based on anthropogenic heritage and the location of the happening that involves attractive natural elements. Concerning the ethnographical events, almost all the elements that animate the tourist destinations are included: wish for meeting new cultures, civilizations and places; recreation; relaxing; hobby; pleasure (at the participants' side) and others. A disadvantage related to the ethnographic events in Vojvodina organized by cultural and artistic social clubs and national councils of the national minorities in Vojvodina is lack of adequate accommodation buildings in places where the events are organized. Thus, the participants and the guests are directed to the nearest regional centers, or accommodated in private buildings. Another disadvantage is bad or no connection with the local tourist organizations and the Tourist Organization of Vojvodina, because the employees in tourist organizations are not interested in cooperation.

\section{References}

Aitken, J. 2002. The Role of Events in the Promotion of Cities. In: Proceedings of international conference -Evants and place making, Australian center for event management, Sydney, pp. 3.

Backman, K.S., Backman, M., Uysal, K., Mohr Sunshine, M. 1995. Event tourism: An examination of motivations and activities. Festival Management \& Event Tourism 3, 15-24.

Bjeljac Ž. 1998. Manifestacioni turizam u Vojvodini. Doktorska disertacija u rukopisu. Institut za geografiju, PMF, Novi Sad.
Bjeljac Ž., Ćurčić N. 2003. Turističko propagandne manifestacije kao segment turističke ponude Vojvodine. Zbornik radova Geografskog Instituta " Jovan Cvijić" 51, 51-64.

Bush, J. 200o. The Granite State Consumer Strengthening the Sense of Community. University of New Hampshire, www. ceinfo.unh.edu, 12.12.01.

Dunstan, G. 1994. Becoming Coastwise, the Path of Festivals and Cultural Tourism, Landscape and Lifestyle Choices for the Northern Rivers of NSW, Southern Cross University,

Dugas, K.J., Schweitzer, J.H. 1997. Sense of Community and the Development of Block culture. In: Ronald E. McNair Post Baccalaureate achievement Programme, Michigan state University, www. Msu.edu/socomm/paper1997. htm, 12.12.01.

Getz, D., Wicks, B. 1993. Editorial.w Festival Management \& Event Tourism 1, 1-3.

Jago, L., Shaw, R. 1998. Special events: a conceptual and differential framework. Festival Management \& Event Tourism 5, $21-32$.

Janiskee, R. 1994. Some macro-scale growth trends in America's community festival industry. Festival Management and Event Tourism 2, $10-14$.

Ulrich, D., 1998. Six Practices for creating communities of value, not proximity. In: Hesselbein, Frances, Goldsmith Marshall, Beckhard, R. and Richard F. (eds) The Community of the Future, Jossey-Bass Publishers, San Francisco, pp $155-166$.

Tourist organization of Serbia 2005. Calendar of touristic events in Serbia, Tourist organization of Serbia, Belgrade.

Data from questionnaire

www.duzijanca.co.yu

www.irig.org.yu 